\title{
Pemilihan Cemilan Khas Sampit Terlaris Pada Kedai 24 Dengan Metode AHP (Analytic Hierarchy Process)
}

\author{
${ }^{1}$ Yuli Yanti, ${ }^{2}$ Diah Atika Safitri, ${ }^{3}$ Rendy Alamsyah \\ 123 Universitas Darwan Ali \\ yuliyantifikom@gmail.com, diahatikasafitrii@gmail.com, rendy20alamsyah@gmail.com
}

\begin{abstract}
Determination of best selling Sampit snacks at Kedai 24 is one of the important things, because by determining what products are best selling, Kedai 24 can predict what products should be reproduced. One way that can be done to choose a product is to ask for a decision support system. By determining the decision support system, the shop owner can decide with the right results in choosing the best selling product. There are several choices that apply and there are several choices to choose from in choosing the best selling products. Data analysis uses the Analytical Hierarchical Process (AHP) method, which calculates with various criteria determined by the shop owner. From the October sales report, the criteria for best selling products were chosen, which are the criteria for taste, price and packaging. For alternative choices consisting of Stik, Amplang and Abon. The results of calculations that have been done are obtained the average taste criteria 0.633346 , the average price criteria 0.260498 and the average packaging criteria 0.106156. After calculating with each available alternative, the highest yield is Abon 0.48 .
\end{abstract}

Keywords: AHP, Best-selling product selection, Kedai 24

\begin{abstract}
Abstrak
Penentuan cemilan khas Sampit terlaris pada Kedai 24 adalah salah satu hal yang penting, sebab dengan menentukan produk apa yang terlaris, kedai 24 dapat memprediksi produk apa yang harus diproduksi lebih banyak. Salah satu cara yang dapat dilakukan untuk memilih produk adalah dengan cara menerapkan sistem penunjang keputusan. Dengan menerapkan sistem penunjang keputusan, pemilik kedai dapat memutuskan dengan hasil yang tepat dalam memilih produk terlaris. Ada beberapa kriteria pilihan yang diterapkan dan ada beberapa alternatif pilihan yang dapat dipilih dalam memilih produk yang terlaris. Analisis data menerapkan metode Analytical Hierarchical Process (AHP), yang memungkinkan perhitungan dengan berbagai kriteria yang ditentukan pemilik kedai. Dari laporan penjualan pada bulan Oktober dipilihlah kriteria yang akan digunakan untuk menentukan produk terlaris yaitu kriteria jenis rasa, harga dan kemasan. Untuk alternatif pilihan terdiri dari Stik, Amplang dan Abon. Hasil perhitungan yang telah dilakukan didapatkan rata-rata kriteria rasa sebesar 0,633346, rata-rata kriteria harga sebesar 0,260498 dan rata-rata kriteria kemasan sebesar 0,106156. Setelah dilakukan perhitungan dengan masing-masing alternatif yang ada, didapatkan hasil tertinggi yaitu produk jenis Abon sebesar 0,48.
\end{abstract}

Kata Kunci : AHP, Pemilihan produk terlaris, Kedai 24

ISSN 2715-0143 (online) ISSN 2714-9048 (print)

http://journal.walisongo.ac.id/index.php/jit/ind

WJIT : Walisongo Journal of Information Technology - Vol.2 No. 1 (2020) 


\section{PENDAHULUAN}

Kedai merupakan suatu tempat atau bangunan yang digunakan untuk berjualan makanan maupun makanan ringan atau cemilan. Di Kabupaten Kotawaringin Timur terdapat banyak kedai yang berjualan cemilan khas Sampit. Salah satu kedai yang menjual cemilan khas Sampit adalah Kedai 24.

Kedai 24 merupakan kedai yang memproduksi sekaligus memasarkan produknya sendiri. Namun, dalam implementasinya sering terjadi ketidaksesuaian antara produksi dan pemasaran. Ketidaksesuaian yang terjadi dikarenakan kurangnya pemahaman dari karyawan maupun pemilik kedai dalam menentukan banyaknya produksi. Untuk menentukan banyaknya produksi, Kedai 24 harus mengetahui terlebih dahulu produk apa yang paling diminati atau yang terlaris dari pemasarn yang telah dilakukan.

Dalam penentuan produk terlaris oleh pemilik Kedai 24 menggunakan beberapa kriteria dalam penilaian. Penilaian ini berdasarkan jenis rasa, harga dan kemasan. Demi ketepatan produksi maka pengambilan keputusan yang tepat sangat diperlukan. Penulisan ini bertujuan untuk membangun sebuah sistem pendukung keputusan yang dapat menganalisa pemilihan produk terlaris dengan menggunakan metode Analytic Hierarchy Process (AHP), dimana masing-masing kriteria penilaian dan alternatif pilihan jenis produk dibandingkan satu dengan yang lainnya sehingga memberikan hasil nilai intensitas prioritas yang menghasilkan suatu sistem yang memberikan penilaian terhadap setiap produk.

SPK bertujuan untuk menyediakan informasi, membimbing, memberikan prediksi serta mengarahkan kepada pengguna informasi agar dapat melakukan pengambilan keputusan dengan lebih baik(1). Sistem pendukung keputusan ini membantu melakukan penilaian terhadap produk yang ada, melakukan penilaian kriteria, dan nilai bobot. Hal ini berguna untuk memudahkan pengambil keputusan yang terkait, sehingga akan di dapatkan produk yang paling laris.

Keluaran pertama SPK berupa rincian perhitungan AHP mendapatkan nilai CR dengan konfirmasi apakah sudah dapat melakukan pencarian solusi ataukah masih harus menata kembali tatanan nilai-nilai perbandingan derajat kepentingan tiap-tiap persyaratan (2). Proses sistem pendukung keputusan penentuan produk terlaris akan dilakukan dengan menggunakan metode Analytic Hierarchy Process.

\section{METODE}

a. Pengumpulan Data

Metode deskriptif analitik yang digunakan dalam penelitian ini adalah observasi dan wawancara kepada pemilik kedai. Data sekunder diambil melalui berbagai media, seperti: internet, jurnal dan artikel-artikel sehingga didapatkan informasi mengenai penilaian pemilihan produk. Selanjutnya data diolah dengan menggunakan pendekatan proses hierarki analitis (AHP) untuk 
Pemilihan Cemilan Khas Sampit Terlaris Pada Kedai 24 Dengan Metode AHP (Analytic Hierarchy Process)

menentukan kriteria pemilihan produk terlaris yang akan digunakan. b. Tahap Penelitian

Tahapan penelitian yang dilakukan dimulai dengan menetukan masalah, pemilihan kriteria, komputasi AHP, perhitungan analisis data dan kesimpulan.

c. Menentukan Masalah dan Pemilihan Kriteria

Sasaran yang ingin dicapai dalam penelitian ini adalah mendapatkan cara penilaian pemilihan produk terlaris. Kriteria penilaian dipilih dan diuji menggunakan metode AHP sesuai dengan kebutuhan produksi. Kriteriakriteria yang telah ditetapkan akan dimasukkan dalam tabel perbandingan dua kriteria berpasangan. Kriteria-kriteria yang digunakan adalah jenis rasa, harga dan kemasan.

Tabel Skala dasar perbandingan berpasangan

\begin{tabular}{|c|l|}
\hline $\begin{array}{c}\text { Intensitas } \\
\text { kepentingan }\end{array}$ & \multicolumn{1}{|c|}{ Keterangan } \\
\hline 1 & Kedua Elemen sama pentingnya. \\
\hline 3 & $\begin{array}{l}\text { Elemen yang satu sedikit lebih penting daripada } \\
\text { elemen yang lainnya. }\end{array}$ \\
\hline 5 & Elemen yang satu lebih penting daripada yang lainnya \\
\hline 7 & $\begin{array}{l}\text { Satu elemen jelas lebih mutlak penting daripada } \\
\text { elemen lainnya. }\end{array}$ \\
\hline 9 & Satu elemen mutlak penting daripada elemen lainnya \\
\hline $2,4,6,8$ & $\begin{array}{l}\text { Nilai-nilai antara dua nilai pertimbangan- } \\
\text { pertimbangan yang berdekatan. }\end{array}$ \\
\hline
\end{tabular}

Dalam Hierarchy keputusan ini terdapat objek yang akan dibahas atau goal, kriteria dan alternatif (3). Berikut ini adalah gambar dari struktur Hierarchy keputusan yang digunakan

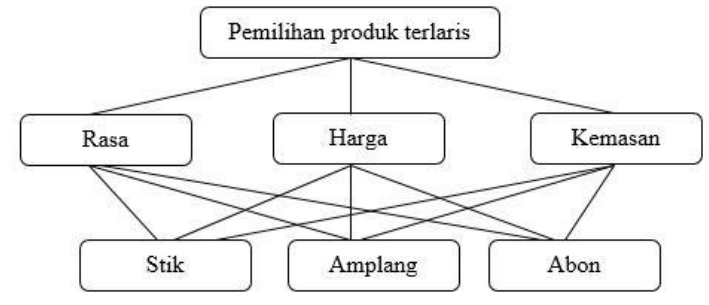

Gambar hierarki metode AHP pemilihan jenis produk terlaris

\section{KERANGKA TEORI}

Sistem Pendukung Keputusan merupakan sistem informasi interaktif yang menyediakan informasi, pemodelan, dan pemanipulasian data (4). Sistem pendukung keputusan dapat didefinisikan sebagai sebuah sistem yang dimaksudkan untuk mendukung para pengambil keputusan manajerial dalam situasi keputusan tidakterstruktur (5). Tindakan memilih strategi atau aksi yang diyakini manajer akan memberikan solusi terbaik atas sesuatu itu disebut pengambilan keputusan(6). Pada dasarnya SPK dirancang untuk mendukung seluruh tahap pengambilan keputusan mulai dari mengidentifikasi masalah, memilih data yang relevan, menentukan pendekatan yang digunakan dalam proses pengambilan keputusan, sampai mengevaluasi pemilihan alternatif (7).

Analytical Hierarchy Process (AHP) adalah metode pencarian keputusan yang akan menghasilkan hasil keputusan yang rasional (8). Analytical Hierarchical Process (AHP) merupakan hierarki dengan input atau masukan utama berupa 
pandangan manusia. Metode AHP ini membantu memecahkan persoalan yang kompleks dengan menstruktur suatu hirarki kriteria, pihak yang berkepentingan, hasil dan dengan menarik berbagai pertimbangan guna mengembangkan bobot atau prioritas (9).

AHP banyak digunakan untuk mengekspresikan pengambilan suatu keputusan yang sangat efektif dari suatu permasalahan yang komplek. Penentuan prioritas dengan metode AHP dilakukan melalui beberapa tahapan yaitu(10):

a. Menyusun hierarki.

b. Menilai kriteria dan alternatif.

c. Memilih prioritas.

d. Menentukan nilai konsistensi logis.

Di dalam mengambil keputusan, penting untuk diketahui baik tidaknya nilai konsistensi yang digunakan. Adapun langkah-langkah yang harus dilakukan adalah:

1) Menghitung nilai perbandingan yang sudah ditetapkan dengan membagi nilai skala yang ada di setiap sel dibagi dengan nilai sel prioritas.

2) Hasil pehitungan dari angkal no. 1 di masing-masing sel dibagi dengan jumlah total di masingmasing kolom.

3) Mencari Eigen dengan cara menghitung ratarata per baris.

4) Mencari Lamda $(\lambda)$ dengan cara mengalikan masing-masing nilai eigen per baris dengan jumlah total per kolom.

5) Mencari lamda ( $\lambda$ maks) dengan cara menjumlahkan hasil lamda. e. Menentukan nilai indeks konsistensi (CI) Rumus yang digunakan sebagai berikut:

$$
C I=\frac{\lambda \max -\mathrm{n}}{n-1}
$$

Keterangan:

$\mathrm{n}=$ banyaknya kreteria yang digunakan.

f. Menetukan rasio konsistensi (CR) Rumus yang digunakan sebagai berikut:

Keterangan:

$$
C R=\frac{\mathrm{CI}}{R I}
$$

$\mathrm{CR}=$ Rasio Konsistensi

$\mathrm{CI}=$ Indeks Konsistensi

RI = Indeks Random Konsistensi

g. Memeriksa konsistensi hierarki. Jika hasil perhitungan nilai rasio konsistensi lebih dari 10\%, maka harus diperbaiki atau dihitung ulang. Tapi jika rasio konsistensi kurang atau sama dengan 0,1 maka dapat dinyatakan benar nilai perhitungannya.

Nilai RI atau index random seperti terlihat pada tabel 1 .

Tabel Nilai RI

\begin{tabular}{|c|c|}
\hline $\mathrm{N}$ & $\mathrm{RI}$ \\
\hline 1 & 0 \\
\hline 2 & 0 \\
\hline 3 & 0.58 \\
\hline 4 & 0.90 \\
\hline 5 & 1.12 \\
\hline 6 & 1.24 \\
\hline 7 & 1.32 \\
\hline 8 & 1.41 \\
\hline 9 & 1.45 \\
\hline 10 & 1.49 \\
\hline 11 & 1.51 \\
\hline 12 & 1.58 \\
\hline
\end{tabular}


Pemilihan Cemilan Khas Sampit Terlaris Pada Kedai 24 Dengan Metode AHP (Analytic Hierarchy Process)

\section{PEMBAHASAN}

Dalam penelitian ini menggunakan teknik observasi dan wawancara langsung terhadap pemilik Kedai 24. Data yang digunakan untuk melakukan penelitian yaitu data penjualan pada bulan Oktober. Kriteria yang digunakan pada penelitian ini yaitu jenis rasa, harga dan kemasan. Untuk alternatif pilihan yaitu Stik, Amplang dan Abon.

Dalam Perhitungan dilakukan dari menghitung prioritas keseluruhan kriteria sampai menghasilkan prioritas penilaian produk terlaris. Hasil yang diperoleh dari penelitian yang dilakukan dapat disajikan sebagai berikut:

Perbandingan masing- masing kriteria

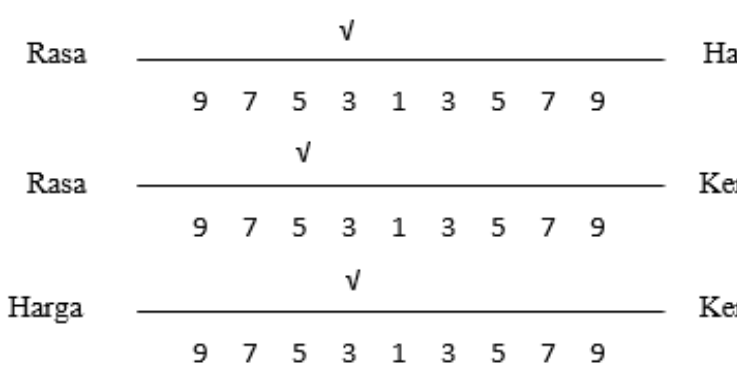

Matriks perbandingan kriteria Tabel Matriks Perbandingan Kriteria

\begin{tabular}{|c|c|c|c|c|c|c|c|c|}
\hline Kriteria & Rasa & Harga & Kemasan & & Nilai Eigen & & Jumlah & rata-rata \\
\hline Rasa & 1,00 & 3,00 & 5,00 & 0,652174 & 0,692308 & 0,555556 & 1,900037 & 0,633346 \\
\hline Harga & 0,33 & 1,00 & 3,00 & 0,217391 & 0,230769 & 0,333333 & 0,781494 & 0,260498 \\
\hline Kemasan & 0,20 & 0,33 & 1,00 & 0,130435 & 0,076923 & 0,111111 & 0,318469 & 0,106156 \\
\hline Jumlah & 1,53 & 4,33 & 9,00 & & & & & 1 \\
\hline Nilail & 3,055361 & & & & & & & \\
\hline $\mathrm{Cl}$ & 0,027681 & & & & & & & \\
\hline CR & 0,047725 & & & & & & & \\
\hline
\end{tabular}

Matriks perbandingan alternatif pada kriteria Rasa

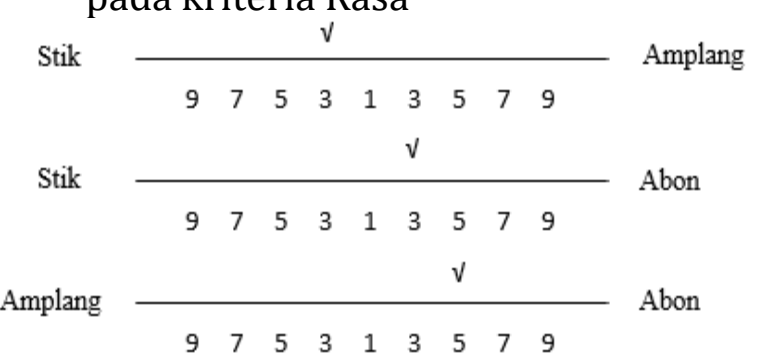

Matriks perbandingan alternatif pada kriteria Harga

Stik

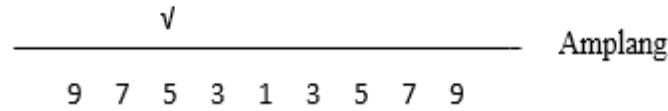

Stik

$\sqrt{ }$

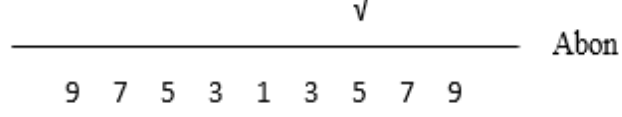

Amplang Abon

Tabel Matriks Alternatif Harga

\begin{tabular}{|l|r|r|r|r|r|r|r|r|}
\hline \multicolumn{1}{|c|}{ HARGA } & \multicolumn{1}{c|}{ Stik } & Amplang & \multicolumn{1}{c|}{ Abon } & \multicolumn{3}{|c|}{ Nilai Eigen } & Jumlah & rata-rata \\
\hline Stik & 1,00 & 5,00 & 5,00 & 0,714286 & 0,454545 & 0,806452 & 1,975283 & 0,658428 \\
\hline Amplang & 0,20 & 1,00 & 0,20 & 0,142857 & 0,090909 & 0,032258 & 0,266024 & 0,088675 \\
\hline Abon & 0,20 & 5,00 & 1,00 & 0,142857 & 0,454545 & 0,16129 & 0,758693 & 0,252898 \\
\hline Jumlah & 1,40 & 11,00 & 6,20 & & & & & 1 \\
\hline & & & & & & & & \\
\hline Nilai $\lambda$ & 3,465186 & & & & & & & \\
\hline Cl & 0,232593 & & & & & & & \\
\hline CR & 0,401023 & & & & & & \\
\hline
\end{tabular}


${ }^{1}$ Yuli Yanti, ${ }^{2}$ Diah Atika Safitri, ${ }^{3}$ Rendy Alamsyah

Matriks perbandingan alternatif pada kriteria Kemasan

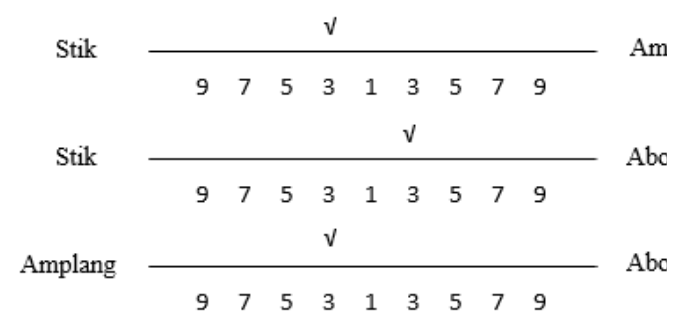

Tabel Matriks Alternatif Rasa

\begin{tabular}{|l|r|r|r|r|r|r|r|r|}
\hline \multicolumn{1}{|c|}{ RASA } & \multicolumn{1}{c|}{ Stik } & Amplang & \multicolumn{1}{c|}{ Abon } & \multicolumn{3}{|c|}{ Nilai Eigen } & Jumlah & rata-rata \\
\hline Stik & \multicolumn{1}{|c|}{1,00} & 3,00 & 0,33 & 0,230769 & 0,333333 & 0,217391 & 0,781494 & 0,260498 \\
\hline Amplang & 0,33 & 1,00 & 0,20 & 0,076923 & 0,111111 & 0,130435 & 0,318469 & 0,106156 \\
\hline Abon & 3,00 & 5,00 & 1,00 & 0,692308 & 0,555556 & 0,652174 & 1,900037 & 0,633346 \\
\hline Jumlah & 4,33 & 9,00 & 1,53 & & & & & 1 \\
\hline & & & & & & & & \\
\hline Nilai $\lambda$ & 3,055361 & & & & & & \\
\hline Cl & 0,027681 & & & & & & \\
\hline CR & 0,047725 & & & & & & \\
\hline
\end{tabular}

Tabel Matriks Alternatif Kemasan

\begin{tabular}{l|l|r|r|r|r|r|r|r|r|}
\hline KEMASAN & \multicolumn{1}{|c|}{ Stik } & Amplang & Abon & \multicolumn{3}{|c|}{ Nila Eigen } & Jumlah & rata-rata \\
\hline Stik & 1,00 & 3,00 & 3,00 & 0,6 & 0,692308 & 0,428571 & 1,720879 & 0,573626 \\
\hline Amplang & 0,33 & 1,00 & 3,00 & 0,2 & 0,230769 & 0,428571 & 0,859341 & 0,286447 \\
\hline Abon & 0,33 & 0,33 & 1,00 & 0,2 & 0,076923 & 0,142857 & 0,41978 & 0,139927 \\
\hline Jumlah & 1,67 & 4,33 & 7,00 & & & & & 1 \\
\hline & & & & & & & \\
\hline & Nilai $\lambda$ & 3,176801 & & & & & & \\
\hline Cl & 0,0884 & & & & & & \\
\hline CR & 0,152415 & & & & & \\
\hline
\end{tabular}

Hasil perengkingan
Tabel Hasil Perengkingan

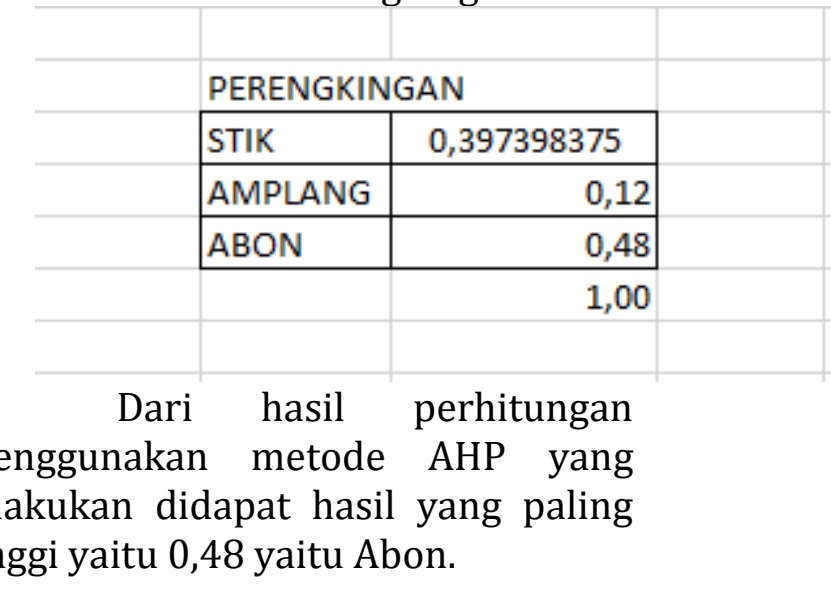

\section{PENUTUP}

Dari perhitungan yang telah dilakukan didapatkan rata-rata kriteria rasa sebesar 0,633346 , ratarata kriteria harga sebesar 0,260498 dan rata-rata kriteria kemasan sebesar 0,106156. Setelah dilakukan perhitungan dengan masing-masing alternatif yang ada, didapatkan hasil tertinggi yaitu produk jenis Abon sebesar 0,48 . Sehingga pemilik kedai seharusnya memproduksi jenis produk Abon lebih banyak daripada jenis produk Stik dan Amplang. 
Pemilihan Cemilan Khas Sampit Terlaris Pada Kedai 24 Dengan Metode AHP (Analytic Hierarchy Process)

\section{REFERENCES}

Simanungkalit, R. P., Moengin, P., \& Adisuwiryo, S. (2017). Perancangan Sistem Pendukung Keputusan Untuk Pemilihan Alternatif Supplierbahan Bakupada Pt. Tesena Inovindo. Seminar Nasional Cendekiawan ke 3 Buku 2

Bachtiar, L., \& Kusrini, K. (2018). Analisis Pemilihan Calon Penerima Beasiswa Daerah dengan Metode Analytical Hierarchy Process dan Profile Matching (Studi Kasus: Universitas Darwan Ali, Sampit, Kalimantan Tengah). Jurnal Bangkit Indonesia, 7(2), 23.

Sunarsa, S., \& Handayani, R. (2016). Sistem Pendukung Keputusan Pemilihan Laptop Untuk Karyawan Pada Pt.Indotekno Dengan Menggunakan Metode Analitycal Hierarchy Process. JITK (Jurnal Ilmu Pengetahuan Dan Teknologi Komputer), 2(1), 5-10.

Suherdi, R., Taufiq, R., Yanuardi, Y., \& Permana, A. (2018). Penerapan Metode Ahp Dalam Sistem Pendukung Keputusan Kenaikan Pangkat Pegawai Di Badan Kepegawaian Dan Pengembagan Sumber Daya Manusia Kota Tangerang. SINTAK, 2.

Firdaus, I. H., Abdillah, G., \& Renaldi, F. (2016). Sistem Pendukung Keputusan Penentuan Karyawan Terbaik Menggunakan Metode Ahp Dan Topsis. Seminar Nasional Teknologi Informasi dan Komunikasi 2016 (SENTIKA 2016).

Riyanto, E. A, \& Haryanti, T. (2017). Sistem Pendukung Keputusan Pemilihan Teller Pooling Terbaik Pada PT. Bca Tbk. Dengan Metode Saw (Simple Additive Weighting). Pilar Nusa Mandiri, 13(1), 128-135.

Mustofa, H., \& Mahfudh, A. A. (2019). Klasifikasi Berita Hoax Dengan Menggunakan Metode Naive Bayes. Walisongo Journal of Information Technology, 1(1), 1-12

Magdalena, H. (2012). Sistem Pendukung Keputusan Untuk Menentukan Mahasiswa Lulusan Terbaik Di Perguruan Tinggi (Studi Kasus Stmik Atma Luhur Pangkalpinang). Seminar Nasional Teknologi Informasi dan Komunikasi 2012 (SENTIKA 2012).

Saragih, S. H. (2013). Penerapan Metode Analytical Hierarchy Process (AHP) Pada Sistem Pendukung Keputusan Pemilihan Laptop. Pelita Informatika Budi Darma, 4(2), 82-88.

Ranius, A. Y. (2014). Sistem Pendukung Keputusan Memilih Perguruan Tinggi Swasta di Palembang sebagai Pilihan Tempat Kuliah. Seminar Nasional Bisnis dan Teknologi 2014.

Umar, R., Fadlil, A., \& Yuminah. Sistem Pendukung Keputusan dengan Metode AHP untuk Penilaian Kompetensi Soft Skill Karyawan. Khazanah Informatika, 4(1). 
${ }^{1}$ Yuli Yanti, ${ }^{2}$ Diah Atika Safitri, ${ }^{3}$ Rendy Alamsyah

This page intentionally left blank.

48 | WJIT : Walisongo Journal of Information Technology - Vol.2 No. 1 (2020) 